a situation they encountered, but felt powerless to resolve it.

"We were in seeing the patient and there were four medical students in there and this girl had already sat through an hour with me going through a complete history and physical. And then, the staff [clinical teacher] decided that he would use her for the rest of the two hours for all of us to do the exam on her and she had no idea why we were there ... One of the medical students was looking at her fundi and he couldn't see them. So, the staff was yelling, "Any idiot can see the optic fundus. How can you not see it? I can see it. Look! Why can't you see it?" Then he said, "I want each and every one of you to keep looking until you see it." So the poor girl is getting blinded by four of us trying to see her fundi ... He was just so inappropriate, the poor girl was almost in tears ... We were all very intimidated; we thought it was inappropriate and we all talked about it later, but he [the clinical teacher] put us all in a position where we were scared to death of him. We were afraid to say anything [although] he was probably wrong."

\section{Comment}

Previous research indicates that medical students experience ethical dilemmas concerning patient care; our study confirms this and goes further by identifying three types of ethical dilemma characteristic of early clinical training. It also suggests that these dilemmas are seldom resolved during medical school. We hope that by learning to recognise and explore these ethical dilemmas medical educators will be able to expose, and ultimately dismantle, deleterious aspects of the "hidden curriculum" which currently hinder the ethical growth of medical students.

Dr Sophia Ahmed helped conceive the study and carry out the survey, and Dr April Boyd helped with statistical analysis. Dr Peter Singer, Dr Philip Hébert, and Walter Atkins advised the authors or commented on drafts of this paper.

Contributors: All five authors conceived and carried out the study, analysed the data from the survey and focus groups, and wrote the manuscript. DWR is the guarantor.

Funding: Faculty of Medicine, University of Toronto.

Competing interests: None declared.

1 Hafferty FW, Franks R. The hidden curriculum, ethics teaching, and the structure of medical education. Acad Med 1994;69:861-71.

2 Swenson SL, Rothstein JA. Navigating the wards: teaching medical students to use their moral compasses. Acad Med 1996;71:591-4.

3 St Onge J. Medical education must make room for student-specific ethical dilemmas. Can Med Assoc J 1997;156:1175-7.

4 Bisonette R, O'Shea RM, Horwitz M, Route CF. A data-generated basis for medical ethics education: categorizing issues experienced by students during clinical training. Acad Med 1995;70:1035-7.

5 Feudtner C, Christakis DA, Christakis NA. Do clinical students suffer ethical erosion? Students' perceptions of their ethical and personal development. Acad Med 1994:69:670-9.

(Accepted 17 November 2000)

\title{
Sex differences in speed of emergence and quality of recovery after anaesthesia: cohort study
}

\author{
Paul S Myles, Andrew D M McLeod, Jennifer O Hunt, Helen Fletcher
}

Department of Anaesthesia and Pain Management, Alfred Hospital, Prahran, Victoria 3181, Australia Paul S Myles head of research Andrew D M McLeod specialist registrar Jennifer O Hunt clinical trials coordinator

Helen Fletcher research nurse Correspondence to: P S Myles p.myles@alfred. org.au

BMJ 2001;322:710-1
Recent evidence shows that postoperative recovery may differ between men and women. ${ }^{12}$ We planned a prospective cohort study to examine the impact of gender on postoperative outcome. This was associated with a trial investigating the effectiveness of several anaesthetic regimens. ${ }^{3}$

\section{Participants, methods, and results}

After obtaining ethics committee approval and informed consent, we studied 463 adult patients undergoing elective inpatient surgery. An observer experienced in postoperative review followed up all patients daily until the third postoperative day. The primary end point was quality of recovery, as measured by a quality of recovery score consisting of nine (range $0-18$ ) items. ${ }^{4}$ Secondary end points included recovery times and the incidence of complications (postoperative nausea and vomiting, headache, backache, and sore throat).

Data were analysed using $t$ tests or generalised linear models (to adjust for the covariates of patients' age, American Society of Anesthesiologists status, and extent and duration of surgery). Associations were described using $\chi^{2}$, risk ratios, and 95\% confidence intervals. Cox proportional hazards was used to adjust for the covariates to identify the effect of gender on the pattern of recovery.

The men $(n=241)$ and women $(n=222)$ in our study were similar in terms of age, American Society of Anesthesiologists physical status, and type, duration, and extent of surgery. Women were more likely to have a history of postoperative nausea and vomiting (42 $(19 \%)$ women $v 18(7.4 \%)$ men, $\mathrm{P}<0.001)$ and to have received prophylactic antiemetic agents (102 (46\%) women $v 70(29 \%)$ men, $\mathrm{P}<0.001)$.

Women emerged significantly more quickly than men (table), and overall quality of recovery was worse (quality of recovery score averaged over time: women 15.7 (95\% confidence interval 15.6 to 16.0$)$; men 16.3 (16.2 to 16.5$) ; \mathrm{P}=0.024)$. Women had a slower return to baseline health status, as determined by their quality of recovery score (hazard ratio 0.75 (0.59 to 0.95 ), $\mathrm{P}=0.005$ ), and were more likely to have postoperative complications (table). All these findings were similar when analysed separately for each anaesthetic regimen and type of surgery (results not shown).

\section{Comment}

We found that women emerged more quickly than men from general anaesthesia but had a 25\% slower rate of return to their preoperative health status. They 
also reported complications more often than did men. These complications are traditionally termed "minor" but are common after surgery, and more rapid emergence may not translate to earlier discharge from the recovery room if the patient's condition has to be stabilised. This may explain the lack of difference between groups for eligibility for discharge from the recovery room.

Underlying physiological differences partly account for variation in the effects of anaesthesia. Sex hormones can cause functional changes in the $\gamma$-aminobutyric acid receptor, the site of action of most intravenous anaesthetic drugs. ${ }^{5}$ Our study confirms that women emerge faster when propofol has been used, ${ }^{1}$ and it extends the findings to include anaesthesia with volatile agents such as isoflurane and sevoflurane. Postoperative nausea and vomiting in women has been related to the phase of the menstrual cycle, and women have a higher incidence of migraine and tension headaches generally (a risk factor for postoperative headache). Postoperative backache may be attributed to immobility of the lumbar spine during surgery, and there are anatomical differences between men and women.

The higher incidence of some complications among women may be attributable to greater willingness to report them. However, participants in this study were directly questioned about nausea, headache, backache, and sore throat rather than being obliged to mention them without prompting. This makes it more likely that the differences in outcome between the sexes, which have previously received limited attention, are genuine and important.

We thank the anaesthetists and recovery room nursing staff who cooperated with this study.

Contributors: PSM conceived and designed the study, analysed the data, and wrote the final drafts of the paper. ADMMcL performed a literature review, contributed to data interpretation, and wrote the first draft of the paper. $\mathrm{JOH}$ and $\mathrm{HF}$ recruited most of the patients in the study, collected all the postoperative data, carried out data entry, and helped to write the paper. PSM is the guarantor.
Speed of emergence and incidence of complications after anaesthesia. Figures are means $(95 \% \mathrm{Cl})$ or numbers (percentage) unless stated otherwise

\begin{tabular}{|c|c|c|c|c|}
\hline & $\begin{array}{c}\text { Men } \\
(\mathrm{n}=241)\end{array}$ & $\begin{array}{l}\text { Women } \\
(\mathrm{n}=222)\end{array}$ & Risk ratio $(95 \% \mathrm{CI})$ & $P$ value \\
\hline \multicolumn{5}{|l|}{ Recovery times (minutes): } \\
\hline Eye opening & 13.4 (12.4 to 14.3$)$ & 11.3 (10.4 to 12.32$)$ & - & 0.003 \\
\hline Obeying commands & $15.3(14.1$ to 16.4$)$ & 12.4 (11.3 to 13.7$)$ & - & 0.002 \\
\hline $\begin{array}{l}\text { Discharge from recovery } \\
\text { room (when eligible) }\end{array}$ & 64 (60 to 67$)$ & 66 (63 to 70) & - & 0.27 \\
\hline \multicolumn{5}{|l|}{ Complications: } \\
\hline \multicolumn{5}{|c|}{ Postoperative nausea and vomiting: } \\
\hline In recovery room & $37(16)$ & $61(28)$ & $1.48(1.1$ to 1.9$)$ & 0.001 \\
\hline Day 1 & $110(47)$ & $160(73)$ & $1.65(1.4$ to 2.0$)$ & $<0.001$ \\
\hline Day 2 & $30(14)$ & $73(33)$ & 1.94 (1.4 to 2.7 ) & $<0.001$ \\
\hline Day 3 & $17(7.8)$ & $47(22)$ & 2.05 (1.4 to 3.1) & $<0.001$ \\
\hline \multicolumn{5}{|l|}{ Headache: } \\
\hline Day 1 & $65(28)$ & $79(36)$ & $1.2(0.97$ to 1.5$)$ & 0.077 \\
\hline Day 2 & $29(13)$ & $53(24)$ & 1.51 (1.1 to 2.1$)$ & 0.003 \\
\hline Day 3 & $25(12)$ & $33(16)$ & $1.2(0.8$ to 1.6$)$ & 0.23 \\
\hline \multicolumn{5}{|l|}{ Backache: } \\
\hline Day 1 & $30(13)$ & $52(24)$ & 1.49 (1.1 to 2.0$)$ & 0.003 \\
\hline Day 2 & $32(15)$ & $39(18)$ & $1.14(0.86$ to 1.5$)$ & 0.34 \\
\hline Day 3 & $20(9.3)$ & $32(15)$ & $1.36(0.95$ to 1.9$)$ & 0.065 \\
\hline \multicolumn{5}{|l|}{ Sore throat: } \\
\hline Day 1 & $92(40)$ & $87(40)$ & 0.99 (0.83 to 1.2$)$ & 0.95 \\
\hline Day 2 & $51(23)$ & $48(22)$ & 0.97 (0.78 to 1.2$)$ & 0.77 \\
\hline Day 3 & $29(14)$ & $33(16)$ & 1.09 (0.82 to 1.5$)$ & 0.53 \\
\hline
\end{tabular}

Funding: This study was supported by the Abbott/ Australian Society of Anaesthetists Research Grant (1996) and a research grant from the Alfred Research Trust (1997).

Competing interests: None declared.

1 Gan TJ, Glass PS, Sigl J, Sebel P, Payne F, Rosow C, et al. Women emerge from general anesthesia with propofol/alfentanil/nitrous oxide faster than men. Anesthesiology 1999;90:1283-7

2 Myles PS, Williams DL, Hendrata M, Anderson H, Weeks AM. Patient satisfaction after anaesthesia and surgery: results of a prospective survey of 10,811 patients. Br J Anaesth 2000;84:6-10.

3 Myles PS, Hunt JO, Fletcher H, Smart J, Jackson T. Part I: propofol, thiopental, sevoflurane, and isoflurane- - a randomized, controlled trial of effectiveness. Anesth Analg 2000;91:1163-9.

4 Myles PS, Hunt JO, Nightingale CE, Fletcher H, Beh T, Tanil D, et al. Development and psychometric testing of a quality of recovery score after general anesthesia and surgery in adults. Anesth Analg 1999;88:83-90.

5 Frye CA, Duncan JE. Progesterone metabolites, effective at the $\mathrm{GABA}_{\mathrm{A}}$ receptor complex, attenuate pain sensitivity in rats. Brain Res 1994:643:194-203

(Accepted 18 December 2000)

\section{A memorable patient \\ Clinical and communication skills conquer all}

I had just started as a casualty officer in a rural part of England. My next patient was an 11 year old boy with a fishing hook in his finger. As I drew back the curtains and entered the cubicle, the child and his parents were slightly taken aback by my appearance. It was probably the first time that they were so close to a brown person. I am an Irish born UK graduate of Indian descent, but my skullcap and beard probably made me look like an Afghan rebel or a rabbi.

After the introductions were over, I turned my attention to John. He was a bit small for his age and I had to kneel down to examine his finger properly. He was not squeamish about his "harpooned" finger, though, and he proudly showed it off to me. I explained to him-and his parents-that because of the barb on the hook, I would have to push it all the way through his finger to get it out. I also explained that I would have to numb the finger by using a ring block.

While mum was a bit apprehensive about the whole thing, dad had seen it all before, and he nodded his head in agreement. I turned back to John to gauge his reaction. His eyes were open wide, and his jaw had dropped. He stared at me for a few seconds and then swallowed nervously. Finally he plucked up courage and said gravely: "I trust you, you're a doctor."

I was both surprised and relieved. His magic words had made my day. Although I had only seen it once before, the ring block worked well, and the hook was soon out. Undoubtedly, my success was due to John's cooperative and trusting attitude.

Whenever I'm feeling low, I think of John's magic words "I trust you, you're a doctor."

A F Dinah senior house officer, trauma and orthopaedics, Romford, Essex We welcome articles of up to 600 words on topics such as A memorable patient, A paper that changed my practice, My most unfortunate mistake, or any other piece conveying instruction, pathos, or humour. If possible the article should be supplied on a disk. Permission is needed from the patient or a relative if an identifiable patient is referred to. We also welcome contributions for "Endpieces," consisting of quotations of up to 80 words (but most are considerably shorter) from any source, ancient or modern, which have appealed to the reader. 